\title{
Steven Klepper: Recipient of the 2011 Global Award for Entrepreneurship Research
}

\author{
Pontus Braunerhjelm • Bo Carlsson
}

Accepted: 1 July 2011/Published online: 19 August 2011

(C) Research Institute of Industrial Economics 2011. This article is published with open access at Springerlink.com

\begin{abstract}
This article reviews the academic contributions of the 2011 receiver of the Global Award for Entrepreneurship Research, Professor Steven Klepper, Carnegie Mellon University. The Global Award consists of 100,000 Euro and a statuette of the internationally renowned Swedish sculpture Carl Milles. Klepper has made breakthrough analyses in the realm of industrial dynamics, emphasizing the regularities in the time paths of entry of new producers, exit of incumbent firms, spin-offs and innovation. His work is predominantly empirical but he has also played an essential role in developing more rigorous theoretical models of phenomena such as spin-offs. Of particular importance is how Klepper has managed to link traditional neoclassical models with evolutionary theory as well as entrepreneurship research with mainstream economics.
\end{abstract}

P. Braunerhjelm $(\bowtie)$

Chairman of the Prize Committee, Swedish

Entrepreneurship Forum, Kungsgatan 33, Stockholm,

Sweden

e-mail: pontus.braunerhjelm@entreprenorskapsforum.se

P. Braunerhjelm

Department of Transport and Economics, Royal Institute of Technology, 10044 Stockholm, Sweden

B. Carlsson

Member of the Prize Committee, Weatherhead School of Management, Department of Economics, Case Western

Reserve University, Cleveland, $\mathrm{OH}$, USA
Keywords Global award · Industrial dynamics · Spin-offs · Entrepreneurship · Innovation

JEL Classifications $\quad \mathrm{L} 26 \cdot \mathrm{M} 13 \cdot \mathrm{O} 31$

\section{Introduction}

Steven Klepper's outstanding scientific achievements have rendered him the Global Award for Entrepreneurship Research for 2011. ${ }^{1}$ Entrepreneurship research draws from and integrates theory and empirics from several subject disciplines, including business and management, economics, and finance. The outcome of entrepreneurship research regularly appears in top tier general management journals, but also in management-based specialist entrepreneurship journals. Steven Klepper, Carnegie Mellon University, personifies this interdisciplinary nature of

\footnotetext{
1 The Global Award is a direct continuation of the International Award for Entrepreneurship and Small Business Research first launched in 1996 by The Swedish Entrepreneurship Forum (then Foundation for Small Business Research, FSF) and the Swedish Agency for Economic and Regional Growth. Since 2009 these two organizations have been joined by The Research Institute of Industrial Economics (IFN), thanks to a generous donation by the Swedish industrialist Rune Andersson, Mellby Gård AB. The prize consists of 100,000 euro and a statuette by the internationally renowned sculpture Carl Milles, the "Hand of God".
} 
entrepreneurship research, integrating elements of traditional neoclassical models with evolutionary theory, thereby bridging some of the gaps between neoclassical and evolutionary theory and between entrepreneurship research and mainstream economics. This may be his most important contribution, serving to anchor entrepreneurship issues as a core field in economic research. This article reviews and reflects upon his impressive and influential corpus of work, which has changed the way scholars, practitioners and policy-makers view the evolution and transformation of industries as well as the ensuing policy implications.

Steven Klepper has made significant contributions to our understanding of the role of new firm entry in innovation, industrial evolution, and economic growth. Klepper's work places entrepreneurship squarely into the mainstream of economic analysis of how industries evolve over time. His work is theoretical and integrative, firmly rooted in empirical observation of historical innovative processes, focusing on explaining "empirical regularities." In looking at the evolution of industries, Klepper explores regularities in the time paths of entry of new producers, exit of incumbent firms, industry output and price, and the rate of product and process innovation. To explain these regularities, he develops theories that feature differences in firm capabilities and the advantages of large firms in appropriating the returns from their innovative efforts. The theories are also used to explain differences in firms' innovative efforts, the composition of their innovative effort and their innovative success.

Klepper's work is founded on systematic longitudinal empirical analyses requiring massive, detailed collections and analyses of historical data on firm entry, exit, size, location, distribution networks, and technological choices. The focus is on the function of new firms in industrial growth as well as the background and heritage of new entrants, particularly as reflected in spin-offs from existing firms.

Klepper's primary contribution to entrepreneurship research is a series of clean and transparent models, founded on systematic longitudinal empirical analyses, explaining how industries evolve, the role of innovation and new firm entry, as well as the experience of founders of new firms in that process. His focus is on explaining patterns of evolution at the industry level by examining data at the firm and product levels. Emphasis is on the function of new firms in industrial growth rather than the features of the entrepreneur or the entrepreneurial firm, and in the mechanisms that lead to new firm formation. Klepper's work has served to deepen our understanding in a number of different areas, especially with regard to the phenomenon known as spin-offs from existing firms. The main thrust is to shed light on the process of industrial evolution and the role of new firms in that process rather than on the entrepreneurial activity per se.

Klepper's work is unusual for an economist in that it requires collection of massive historical longitudinal data (both quantitative and qualitative), often involving detailed and painstaking archival work covering the entire history of each industry he studies. Typically he then looks for "empirical regularities" and proceeds to constructing theoretical explanations to the underlying phenomena, and follows up with a discussion of the implications.

Klepper's work on entrepreneurship can be roughly categorized in three groups, reflecting his intellectual journey over the last few decades. His focus has shifted from the general to the more particular-from patterns of evolution of industries to the historical development of particular industries in detail and then to analyses of the role of prior experience in new firm creation, especially via spinoffs from existing firms. In each of these areas, Klepper has developed simple but powerful models to explain the observed evolutionary processes.

\section{Patterns in the evolution of industries}

One major area in Klepper's work focuses on the evolution of industries, stressing the role of innovation and new entrants as vehicles of introduction of diversity, a crucial element in the evolutionary process. $^{2}$ He has made significant contributions to our understanding of the role of new firm entry in innovation and economic growth. In examining the evolution of industries, Klepper explores patterns in

\footnotetext{
$\overline{2}$ Other areas in Klepper's research involve econometrics (making inferences about unobservable constructs through the use of proxy variables) and criminal justice, taxes, and health issues. Works in these areas are peripheral to the work on entrepreneurship and are not reviewed here.
} 
the time paths of entry of new producers and exit of incumbent firms, resulting in what Klepper refers to as shakeouts in some industries but not in others. He also examines the rate of product and process innovation, distinguishing between the roles of incumbents and new entrants. To explain these regularities, he develops theories that feature differences in firm capabilities and the advantages of large firms in appropriating the returns from their innovative efforts. The theories are also used to explain differences in firms' innovative efforts, the composition of their innovative effort with respect to product and process innovation, and their innovative success. This research has implications for industrial policy encouraging entry of innovative firms and cooperation among incumbents in certain types of activities.

Another critically important area in Klepper's research concerns the integration of entrepreneurship into the theory of industry evolution and economic growth. His early work precedes the widespread introduction of entrepreneurship concepts and research into economics. It is also steeped deeply in the Industrial Dynamics (as distinct from Industrial Organization) tradition, focusing on the forces and processes that generate industry evolution and industry structure rather than on the resulting size distribution of firms at a given time period and its policy implications. Thus, instead of "entrepreneurship," Klepper discusses the introduction and diffusion of product innovations, with new entrants being an important (perhaps the most important) vehicle.

The distinction between product and process innovation is important in Klepper's work. Incumbent firms are viewed as the primary carriers of process innovation, enjoying economies of scale in $R \& D$ because of the ability to spread $R \& D$ costs over large production volumes. Thus, in spite of the empirical fact that new firms are often more innovative (have higher productivity in R\&D as indicated by the number of product innovations in relation to $R \& D$ expenditures) than large incumbents, large firms are able to spread the costs of process innovations over larger output. As a result, they have an advantage in appropriating the returns. The competitive process tends to reduce the profit margins over time, eventually squeezing out entry. By modeling these processes, using both traditional neoclassical concepts and evolutionary ones, Klepper can explain several interesting phenomena, such as the shifts over time in the number and size distribution of firms in an industry and the tendency for process innovation to dominate over product innovation as an industry matures.

In more ways than one, Gort and Klepper (1982) represent the launch of Klepper's research agenda that he has since pursued. Many of the elements are already present, such as in-depth historical data at the product level, analyses of time paths (i.e., dynamics), and the construction of a theory based on the empirical data. The authors attempt to measure and analyze the diffusion of product innovations. They trace the history of diffusion for 46 new products and examine how the diffusion process is related to other aspects of technological change, as well as to price, output, and certain attributes of the relevant markets. In order to explain the product histories, they construct a theory of the development of industries for new products. Their theory combines elements of traditional, neoclassical models (such as economies of scale and the rate of technical change) with evolutionary elements such as changes over time in entry and exit rates and in the rate and sources of innovation. As a result, the structure of new product markets is viewed as determined by a historical sequence.

Klepper and Graddy (1990) is another study introducing dynamic elements into the largely static industrial organization framework. Here the focus is on the evolution of new industries and the determinants of market structure. The authors observe several empirical regularities concerning firm growth rates and industry firm-size distributions, drawing on the industries studied by Gort and Klepper (1982) but extending the observed regularities to gain further insight into the forces governing industry evolution. They construct a model that emphasizes how factors governing the early evolution of industries may shape their market structure at maturity. One observation is that chance events and exogenous factors influence the number of potential entrants to the industry and that the growth rate of incumbents and the ease of imitation of industry leaders will influence the ultimate number and size distribution of firms in the industry. A key feature is the idea that entrants into new industries typically have experience in related technologies-a recurring idea in Klepper's subsequent work. In the model, the key factors driving the 
evolutionary process are the number of potential entrants in each period, the rates at which firms grow in each period, and the ease of imitation of rivals.

In a series of joint papers by Steven Klepper and Wesley Cohen on R\&D and firm size, the authors start with the observation that in many industries there are many business units for which reported $R \& D$ is zero and that the frequency distributions of R\&D intensity tend to be highly skewed (Cohen and Klepper 1992a). They develop a model that provides a new rationale for the stylized fact that larger firms produce fewer innovations per R\&D dollar than smaller firms. The model implies that this relationship does not indicate that larger firms are inefficient at $\mathrm{R} \& \mathrm{D}$, as often supposed, but rather that large size may actually confer an advantage in the conduct of $R \& D$ by allowing the spreading of $R \& D$ expenditures over larger output volumes. Another key idea is the probabilistic (rather than deterministic) nature of R\&D spending and its outcome; chance plays an important and systematic role in conditioning firm R\&D intensities, and firm size plays an important role in conditioning firm R\&D spending.

In Cohen and Klepper (1992b) the starting point is the debate among economists since the writings of Schumpeter concerning the role of firm size in promoting technical advance. Based on Schumpeter's early work (Schumpeter 1911), some argue that the small entrepreneurial firm is the primary vehicle through which new ideas are introduced into the marketplace and that the diversity of ideas and approaches flowing from small firms are important. Small firms, unencumbered by bureaucracy, provide both the freedom and economic incentives that stimulate creativity and agility in response to economic opportunity. Others argue, based on Schumpeter (1942), that only large firms can command the resources necessary to field large research efforts required for major technical advance. While large firms may be more bureaucratic, they provide superior human and capital infrastructure to support innovative activity. Cohen and Klepper suggest that both firm size and technological diversity influence firm R\&D expenditures within industries and argue that there are virtues both to having a large number of small firms in an industry and to consolidating output in a few large firms. They develop a simple model of R\&D investment and show that there is essentially a tradeoff between the appropriability advantage of large firms and the advantages of diversity associated with many small firms.

Klepper and Miller (1995) is the first of several papers concerned with the notion of shakeouts of firms in various industries. In industries characterized by shakeouts, entry exceeds exit by a wide margin during the formative period but then declines sharply after a peak has been reached. Exits (measured as a percentage of the number of producers) tend to remain fairly constant or rise over time. The authors collect data on the patterns of entry and exit for 16 major new manufactured products from their commercial inception through 1980 and develop a model in which entry and exit coordination problems can generate shakeouts. They find that shakeouts are distinguished by entry falling off sharply but rates of exit remaining steady or rising over time.

Cohen and Klepper (1996a) study the relationship between firm size and the nature of innovation over time as industries evolve. Citing previous research they observe that within industries R\&D expenditures increase less than proportionally with firm size (Mansfield 1981), that process R\&D increases relative to product $R \& D$ as the size of the firm increases (Scherer 1991), and that among $R \& D$ intensive industries, the share of $R \& D$ dedicated to process innovation increases with market concentration (Link 1982). They hypothesize that returns to process $R \& D$ depend more on the firm's output at the time it conducts its $R \& D$ than do the returns to product R\&D. In developing a simple model they derive and test predictions about how the fraction of $R \& D$ devoted to process innovation varies with firm size within industries. Their model does not require that small or large firms are innately better or more capable at different types of R\&D in order to explain the observed relationships between firm size and the nature of innovation. Rather, their results suggest that there is a division of innovative labor among firms of different sizes (large firms devote a greater share of their R\&D to process innovation than do small firms), and that this pattern is endogenously determined by the prospects for firm growth due to innovation and appropriability conditions within industries. Also, by linking firm size and the composition of $R \& D$, the model can explain patterns in the evolution of the nature of innovation within industries. For example, incremental and process innovations tend to increase as industries mature. The authors show that while 
such patterns are often interpreted as reflecting exogenous features of the evolution of the underlying technological opportunities, they may in fact be endogenous; if the average firm size increases over time, then their model explains these patterns as an outcome of the evolution of market structure.

Cohen and Klepper (1996b) confirm results reported in their earlier studies and also try to address some unanswered questions: why do large firms spend proportionally more on $\mathrm{R} \& \mathrm{D}$ than smaller firms, even though they have no advantage in $R \& D$ competition and generate fewer innovations per dollar of R\&D? Also, how can large firms survive and prosper in R\&D-intensive industries even though they spend proportionally more on R\&D but get less out of their R\&D than smaller firms? The answer lies in cost spreading of process $R \& D$ costs over larger output volumes in large firms. Cost spreading gives larger firms a greater incentive to undertake $R \& D$, and it allows them a greater return from $R \& D$ than in smaller firms.

Klepper (1996) is Klepper's most widely cited article; it can now be regarded as a "classic." It brings together much of his earlier work on patterns of innovation, entry, exit, and growth. The model of the product life cycle is founded on two basic forces. One is that the ability to appropriate the returns to process $R \& D$ depends critically on the size of the firm. The other is that firms possess different types of expertise and that this leads them to pursue different types of product innovation. The ability of large firms to reap greater benefits than smaller firms from process $R \& D$, in combination with the tendency of firms to grow over time, causes process $R \& D$ to rise over time. Eventually, this puts new entrants at such a cost disadvantage that entry is foreclosed. After entry ceases, firms compete on the basis of size and innovative capability. With exit rates constant or rising slowly over time, the number of firms falls and the diversity of product $R \& D$ is reduced. This causes the number of product innovations and the diversity of competing product variants to decline (Klepper 1996, p. 580).

Klepper (1997) reviews the empirical evidence on the evolution of new industries to examine the extent to which the product life cycle can be applied to the evolution of industries. He examines the automobile industry and compares it to other industries characterized by the product life cycle and then looks at other industries that have not followed the product life cycle. While he finds certain common patterns, there are also important questions needing further research, for example, why, after the number of firms has stabilized and firm market shares have settled down, there are developments not captured by the product life cycle hypothesis, such as innovationbased entry by foreign firms. And why is there a sharp rise in innovation in some industries after they have reached a mature stage?

\section{In-depth historical industry studies}

Another area in which Steven Klepper has made a significant contribution to entrepreneurship research is historical analyses of industrial evolution featuring the role of new firms, especially the key firms that shaped the industry, their origin and experience prior to entry. The studies in this area are based on detailed and painstaking collections and analyses of historical data on firm entry, exit, size, location, distribution networks, and technological choices which shaped the evolution of the composition and size structure of firms in several industries: tires, television receivers, semiconductors, automobiles and penicillin.

Klepper and Simons (2000a) is one of several studies of the emergence and evolution of the U.S. tire industry and its location in Akron, Ohio, and the role of technological innovation in that process. It is also the first to appear in several in-depth industry studies based on collection of archival data spanning several decades. Among the findings are that technological change played a key role in conditioning firm survival. The industry was ultimately dominated by a few early entrants, and long-term survival rates were considerably higher for earlier entrants. Older and larger firms were found to be closer to the technological frontier, which enabled them to survive longer. Firms located in Akron, Ohio, which emerged as the geographic center of the industry, were also found to be closer to the technological frontier, which contributed to their longer survival.

In a subsequent paper, Klepper and Simons (2000b) examine how the U.S. television receiver industry evolved to be an oligopoly dominated by firms that produced radios prior to TVs. Data were collected on the experience of all U.S. radio manufacturers and on the length of survival and rate of 
innovation of all entrants into the industry. This is the first of several articles in which Klepper explores the role of experience in related activities prior to entry. The model emphasizes innovation and heterogeneity among entrants in contributing to a shakeout and the evolution of an oligopolistic market structure. Entry and firm performance are found to depend on two factors: the R\&D productivity of potential entrants and the timing of the entry. Firms that had prior experience in producing radios were more likely to enter TV manufacturing, have entered earlier, had higher innovation rates, achieved greater market shares, and survived longer than other firms. Firm capabilities and the evolution of the TV industry's market structure were critically shaped by firms' experience prior to entry.

Holbrook et al. (2000) studied the nature, sources, and consequences of differences among four of the early entrants into the semiconductor industrySprague Electric, Motorola, Shockley Semiconductor Laboratories, and Fairchild Semiconductor. Case studies of the firms showed that the key differences among them stemmed from the firms' technological goals and activities, and their abilities to integrate $\mathrm{R} \& \mathrm{D}$ and manufacturing. These differences were in turn related to the firms' origins and the varied conditions prevailing upon their entry into the semiconductor industry. An interesting feature in this article is that it explores where the key knowledge resided within the firms that affected their operational and more forward-looking decisions. An important finding is that firms enter new areas to exploit intangible assets initially developed for other purposes. Although the new firms did not themselves have organizational histories (by definition), their founders had histories upon which they drew. The ability of the firms to coordinate $R \& D$ and production was perhaps the most important determinant of their success over time; this, in turn, was largely based on the structures top management set up to facilitate the coordination. Thus, the most important capabilities were those that enabled firms to adapt to technological and market change over time.

In a similar study of the U.S. automobile industry, Klepper (2002a) analyzed the background of each of the 725 firms that entered the U.S. automobile industry between 1895 and 1966. He traced the heritage of every entrant into the industry, including the founders of de novo entrants, and explored how the time of entry and pre-entry experience affected firm survival. He found that the capabilities of the new firms were fundamentally shaped by the experiences of their founders. On average, firms that diversified from related industries into the auto industry outperformed de novo entrants. However, Klepper also found that de novo entrants founded by individuals who worked for the leading automobile firms outperformed all other firms and came to dominate the industry. Klepper argues that automobile firms faced new organizational challenges and that incumbent firms, particularly leading incumbent firms, were particularly good training grounds to learn how to address these challenges. He also discusses the implications of these findings for why both the automobile and semiconductor industries became geographically concentrated in Detroit and Silicon Valley, respectively.

Klepper (2002b) broadened the focus to consider four different industries, all of which experienced sharp shakeouts and evolved to be oligopolies: automobiles, tires, televisions, and penicillin. After the commercial introduction of the respective product, the number of producers in each industry grew initially but then experienced a sharp decline or shakeout. Using an evolutionary model of entry, exit, and firm survival patterns in the four products, Klepper identified some common factors explaining the distinctive evolution in each industry. He found, similarly to his previous studies, that prior experience and early entry conferred competitive advantages through $R \& D$, suggesting that technological change may have played a key role in shaping the evolution of the market structure in each industry and that the evolution of oligopolistic structures was a natural byproduct of technological change rather than the result of market power.

Klepper and Simons (2005) examined the same four industries, focusing more on technological change than on the evolution of market structure. They developed and carried out more discriminating tests of the role of innovation in industry shakeouts. They compared theories in which technological developments trigger shakeouts with theories in which shakeouts are part of a broader evolutionary process shaped by innovation. Their results show consistent patterns in all four industries: early entrants had markedly lower hazard rates by the start of the shakeouts in all four industries and maintained 
these lower hazards as the shakeouts proceeded. Innovation was the driving force behind the longer survival of early entrants and shaped the survival of entrants from all periods.

\section{Entry by spin-offs: heritage and agglomeration}

In a third group of studies, Klepper moves his analyses from the industry level to the firm level. He looks inside new entrants, focusing on the background and heritage of their founders (especially in terms of their competence). In this manner he takes another step in examining firm capabilities by exploring the origins of the auto industry in Detroit and the tire industry in Akron, as well as the semiconductor industry in Silicon Valley, and why these industries came to be located where they are.

In Sinclair et al. (2000), the purpose is to probe the sources of the relationship between experience and manufacturing cost by analyzing the process of cost reduction in detail. The authors estimated learning curves relating unit cost to measures of production experience for 221 specialty chemicals produced by a Fortune 500 company. Detailed records on cost and R\&D coupled with insights from company personnel were used to explain the variation across products in the rate of cost reduction. They found that products that exhibited the strongest relationship between unit cost and measures of production experience were subject to specific initiatives, particularly process $\mathrm{R} \& \mathrm{D}$. Thus, the major finding is that what may look like learning from production experience may reflect the outcome of an incentive-driven $R \& D$ process in which learning from actual production plays a minimal role. This constitutes a re-interpretation of learning-by-doing as first presented by Arrow (1962). It was not production experience as such that led to cost reduction. Instead, building on their training and broad experience with chemical manufacturing processes generally, the R\&D chemists identified costreducing strategies largely by performing experiments in the R\&D lab, and the chemical engineers subsequently figured out how to implement the changes suggested by R\&D. Each exploited a repertoire of solutions to past problems in performing its task. Thus, to the degree that cost reductions benefited from learning from experience, the learning originated from confronting similar technical problems, which yielded know-how of a rather generic variety. The know-how acquired in this learning process is not principally related to the production of any one product but to the more general issue of design and modification of production processes for a broad class of products.

Klepper (2001) is the first of several papers focusing on start-ups in high-tech industries by employees in incumbent firms. In this paper Klepper uses four theoretical perspectives to examine the motivation and competence of employees leaving incumbent firms to start new businesses in the same industry. In the first one (agency theory), spin-offs are modeled as capitalizing on discoveries that employees make in the course of their employment in incumbent firms. In the second perspective (organizational capability theory), spinoffs are portrayed as developing innovations that incumbents are slow to pursue because of organizational limitations. The third perspective (employee learning theory) stresses the connection between spinoffs and employee learning. Spin-offs are viewed as exploiting knowledge their founders learned in their prior employment to compete with their former employers and other firms in the industry. In the fourth perspective, predictions about spin-offs are developed based on the idea that spin-offs are planned in the sense that their parents (incumbent firms) are supportive and helpful. After reviewing the existing literature, Klepper finds that all of the perspectives are lacking in some ways. Nevertheless, a few common themes emerge. For example, founders of spin-offs do not generally capitalize on discoveries financed by their employers. It is not technologies that are appropriated from parents but the broad experiences of the founders that determine their performance. More innovative, successful firms with broader product lines spawn more spin-offs. The broader the experiences of a spin-off's founders, the better its performance. Founders draw primarily on their prior experiences related to their functional positions rather than the specific technologies of their parents.

Klepper and Sleeper (2005) develop some of the ideas in Klepper (2001). Using data from the laser industry, the authors perform a statistical analysis and test a model using detailed data on all laser entrants from the start of the industry through 1994. They find that the probability of a firm spawning a spin-off producing a particular laser was related primarily to the firm's experience producing the laser and not its 
general experience. Nearly all the spin-offs also produced lasers their parents produced. This suggests that in this case spin-offs exploited targeted knowledge from their parents, not the broader general knowledge as in the previous paper. The qualitative evidence suggested that spin-offs initially serviced narrow, targeted niches that overlapped with their parents' markets but over time they also serviced related but different markets than their parents. Another finding is that spin-offs were heavily concentrated among longer-lived firms and that the probability of a firm spawning a spin-off producing a particular laser was an increasing function of the firm's total experience producing the laser. Also, within each laser submarket, spin-offs were found to be responsive to adverse but not to favorable market conditions for entry.

Klepper has also contributed several important and original theoretical papers to the entrepreneurship literature. Together with Peter Thompson, he presented a theoretical model of the emergence of submarkets (defined as market segments, services provided, and geographical area) due to firm heterogeneity. These submarkets are assumed to display different dynamics. The model developed by Klepper and Thompson (2006a) is shown to closely capture real industrial dynamics.

An interesting theoretical model of spin-offs, building on heterogeneous individuals, noisy information and learning, has been suggested by Klepper and Thompson (2007). It relates to the occupational choice model insofar as entry is determined by profitmaximizing agents, but it is a better designed vehicle to explain spin-offs. Basically the model predicts that the more an employee's preferred strategy to obtain a certain firm objective (profit, productivity, etc.) deviates from the weighted average of all employees, the more likely it is that a spin-off will take place. But disagreement with regard to strategies is not sufficient for a spin-off to take place, entry costs must also be taken into account. Hence, the launching of a new spin-off depends on the subjective evaluations of future pay-off and costs by individuals. Dynamics is introduced as heterogeneous individuals receive noisy information that will alter their expectations over time. Similar ideas are pursued in Klepper and Thompson (2006b).

A step further in the analysis of the role and prior experience of founders of new firms was provided by
Klepper (2007). Rather than looking at the formation of a new industry, here Klepper focuses on the agglomeration and geographic concentration of the industry. He uses hypotheses developed in previous papers and applies them to the formation and evolution of the automobile industry in Detroit. The automobile industry was one of the earliest and most extreme examples of an agglomerated industry, but the reasons for the agglomeration remain unclear. Tracing the heritage of all the entrants into the industry from 1895 to 1966 , Klepper finds that the reasons have to do with spin-offs from incumbent firms. He uses a theory in which disagreements lead employees of incumbent firms to found spin-offs in the same industry. Spin-offs were distinctive performers and accounted for the bulk of firms that made it into the ranks of the leaders after 1903. The leading spin-offs were found to be concentrated in the Detroit area, where a disproportionate share of new entrants was spin-offs from incumbent firms. This was largely attributable to Olds Motor Works, Cadillac, Ford, and Buick/GM. These prominent companies were responsible for most of the leading spin-offs, reflecting the tendency of better firms to have more and betterperforming spin-offs. Indeed, Klepper claims that the superior performance of firms in the Detroit area was due largely to the high quality of the spin-offs that located there, suggesting that it was the spin-off process and not any attributes of the Detroit area per $s e$ that caused the industry to be agglomerated there.

A similar analysis is carried out in Buenstorf and Klepper (2009) for the tire industry in Akron, Ohio. The authors extend the analysis in previous papers on the tire industry in Akron through another massive collection of archival data on the formation and evolution of the industry and its location, and the heritage of its founders. The authors contrast the conventional view against an alternative view. The conventional view is that the location of the tire industry in Akron was due to the proximity to the automobile industry in Detroit and that the early concentration of producers in Akron gave rise to Marshallian agglomeration economies associated with labor pooling, specialized input suppliers, and knowledge spillovers. The alternative view features the inheritance of organizational competence as the principal force underlying industry clustering-similar to the formation of the Detroit automobile industry. The findings suggest that the spin-off 
process was the key to the Akron cluster and that agglomeration economies and proximity to markets stressed in the conventional account played a minor role in the clustering of the industry there.

\section{Conclusion}

Steven Klepper is best known for his seminal contributions in the empirical vein of industrial dynamics, stressing the roles of entry, exits, spinoffs and innovation. His carefully elaborated studies have highlighted hitherto unknown mechanisms that cause industries to evolve and transform over time. Klepper is doubtlessly one of the world's leading authorities in this field of research. Making his overall contribution even more impressive is his research on theory, also pushing the modeling frontier forward. Thus, his analytical rigour embraces both empirical and theoretical work.

By linking evolutionary theory with neoclassical models and building entrepreneurship into the analysis of industry evolution, Klepper has made a major contribution to entrepreneurship research and has provided a foundation and an agenda for future research.

Open Access This article is distributed under the terms of the Creative Commons Attribution Noncommercial License which permits any noncommercial use, distribution, and reproduction in any medium, provided the original author(s) and source are credited.

\section{References}

Arrow, K. J. (1962). The economic implications of learning by doing. Review of Economic Studies, 29(3), 155-173.

Buenstorf, G., \& Klepper, S. (2009). Heritage and agglomeration: The Akron tyre cluster revisited. Economic Journal, 119, 705-733.

Cohen, W. M., \& Klepper, S. (1992a). The anatomy of industry R\&D intensity distributions. American Economic Review, 82(4), 773-799.

Cohen, W. M., \& Klepper, S. (1992b). The tradeoff between firm size and diversity in the pursuit of technological progress. Small Business Economics, 4(1), 1-14.

Cohen, W. M., \& Klepper, S. (1996a). Firm size and the nature of innovation within industries: The case of process and product R\&D. Review of Economics and Statistics, 78(2), 232-243.

Cohen, W. M., \& Klepper, S. (1996b). A reprise of size and R\&D. Economic Journal, 106(437), 925-951.

Gort, M., \& Klepper, S. (1982). Time paths in the diffusion of product innovations. Economic Journal, 92(367), 630-653.
Holbrook, D., Cohen, W. M., Hounshell, D. A., \& Klepper, S. (2000). The nature, sources, and consequences of firm differences in the early history of the semiconductor industry. Strategic Management Journal, 21(10-11), 1017-1041.

Klepper, S. (1996). Entry, exit, growth, and innovation over the product life cycle. American Economic Review, 86(3), 562-583.

Klepper, S. (1997). Industry life cycles. Industrial and Corporate Change, 6(1), 145-181.

Klepper, S. (2001). Employee startups in high-tech industries. Industrial and Corporate Change, 10(3), 639-674.

Klepper, S. (2002a). The capabilities of new firms and the evolution of the US automobile industry. Industrial and Corporate Change, 11(4), 645-666.

Klepper, S. (2002b). Firm survival and the evolution of oligopoly. RAND Journal of Economics, 33(1), 37-61.

Klepper, S. (2007). Disagreements, spinoffs, and the evolution of Detroit as the capital of the US automobile industry. Management Science, 53(4), 616-631.

Klepper, S., \& Graddy, E. (1990). The evolution of new industries and the determinants of market structure. RAND Journal of Economics, 21(1), 27-44.

Klepper, S., \& Miller, J. H. (1995). Entry, exit and shakeouts in the United States in new manufactured products. International Journal of Industrial Organization, 13(4), 567-591.

Klepper, S., \& Simons, K. L. (2000a). The making of an oligopoly: Firm survival and technological change in the evolution of the US tire industry. Journal of Political Economy, 108(4), 728-760.

Klepper, S., \& Simons, K. L. (2000b). Dominance by birthright: entry of prior radio producers and competitive ramifications in the US television receiver industry. Strategic Management Journal, 21(10-11), 997-1016.

Klepper, S., \& Simons, K. L. (2005). Industry shakeouts and technological change. International Journal of Industrial Organization, 23(1-2), 23-43.

Klepper, S., \& Sleeper, S. (2005). Entry by spinoffs. Management Science, 51(8), 1291-1306.

Klepper, S., \& Thompson, P. (2006a). Submarkets and the evolution of market structure. RAND Journal of Economics, 37(4), 861-886.

Klepper, S., \& Thompson, P. (2006b). Intra-industry spinoffs. Mimeo: Florida International University.

Klepper, S., \& Thompson, P. (2007). Spinoff entry in high-tech industries: motives and consequences. In F. Malerba \& S. Brusoni (Eds.), Perspectives on innovation. Cambridge: Cambridge University Press.

Link, A. N. (1982). A disaggregated analysis of industrial R\&D: Product versus process innovation. In D. Sahal (Ed.), The transfer and utilization of technical knowledge. Lexington, MA: Lexington Books.

Mansfield, E. (1981). Composition of R\&D expenditures: Relationship to size of firm, concentration, and innovative output. Review of Economics and Statistics, 63(4), 610615 .

Scherer, F. M. (1991). Changing perspectives on the firm size problem. In Z. J. Acs \& D. B. Audretsch (Eds.), Innovation and technological change: an international comparison. New York: Harvester Wheatsheaf. 
Schumpeter, J. A. (1911). Theorie der wirtschaftlichen Entwicklkungen. Leipzig: Duncker and Humblot. Published in English translation as Schumpeter, J. A. (1934) The Theory of Economic Development. Cambridge: Harvard University Press.

Schumpeter, J. A. (1942). Capitalism, Socialism, and Democracy. New York: Harper.
Sinclair, G., Klepper, S., \& Cohen, W. (2000). What's experience got to do with it? Sources of cost reduction in a large specialty chemicals producer. Management Science, $46(1), 28-45$. 